\title{
POTASSIUM FERTILIZATION AND YIELD PARAMETERS OF CARROT
}

\author{
João de Andrade Bonetti ${ }^{1}$, Marcio Roggia Zanuzo ${ }^{2}$, Elvis Constantino Josefer ${ }^{2}$, Renato Correa \\ $\mathrm{Cacho}^{2}$
}

${ }^{1}$ North Carolina State University, Department of Crop and Soil Science, 101 Derieux Place, Campus Box 7620, Raleigh, NC, United State of America, 27695-7620 agro.bonetti@gmail.com;

${ }^{2}$ Universidade Federal do Mato Grosso, Av. Alexandre Ferronato, 1200 - St. Industrial, Sinop - MT, Brasil.

\begin{abstract}
The aim of this study was to evaluate different potassium fertilization levels under topdressing and its influence on growth, health, quality standards and yield in carrot growing factors. The assay was carried out in the experimental area of the Universidade Federal de Mato Grosso - Campi Sinop, State of Mato Grosso - Brazil, in a randomized block design with eight treatments, 64, 128, 192, 256, 320, 384, 448 and $512 \mathrm{~kg} \mathrm{ha}^{-1}$ of $\mathrm{K}_{2} \mathrm{O}$ with three replications. The yield increased linearly with potassium adding, and $448 \mathrm{~kg} \mathrm{ha}^{-1} \mathrm{~K}_{2} \mathrm{O}$ showed the highest yield, and high correlation with increasing root length. $\mathrm{K}_{2} \mathrm{O}$ levels influenced neither the acidity nor the sugar content, and the incidence of Alternaria leaf spot (Alternaria dauci) decreased with potassium levels, also being related to the yield increase.
\end{abstract}

Keywords: Daucus carota, carrot production, root parameters, Alternaria dauci

\section{FERTILIZAÇÃo DE POTÁSSIO E PARÂMETROS DE PRODUÇÃo DE CENOURA}

\section{RESUMO}

O objetivo deste estudo foi avaliar diferentes doses de potássio em adubações de cobertura e a influência sobre fatores de crescimento, sanidade, parâmetros de qualidade e produtividade na cultura da cenoura. O experimento foi conduzido na Universidade Federal de Mato Grosso, em Sinop, State of Mato Grosso, Brazil, MT, em delineamento de blocos casualizados, com tratamentos de $64,128,192,256,320,384,448$ e $512 \mathrm{~kg} \mathrm{ha}^{-1}$ de $\mathrm{K}_{2} \mathrm{O}$ e três repetições. A produtividade apresentou aumento linear em relação às doses de potássio, sendo que $448 \mathrm{~kg} \mathrm{ha}^{-1}$ de $\mathrm{K}_{2} \mathrm{O}$ apresentaram a maior produtividade, tendo alta correlação com o aumento do comprimento de raiz. A acidez e o teor de açúcar não foram influenciados pelas doses de $\mathrm{K}_{2} \mathrm{O}$ e a incidência de Mancha de Alternaria (Alternaria dauci) diminuiu em função do aumento das doses de potássio e também pode estar relacionada ao aumento de produtividade.

Palavras-chave: Daucus carota, produção de cenoura, parâmetros de raiz, Alternaria dauci 


\section{INTRODUCTION}

Carrots are the most tuberous vegetable consumed in Brazil and is also one of the most important cultivated. Due to its short growing cycle, it presents high necessities in mineral fertilization because of the intense biomass production. The importance of balanced plant nutrition is not only in higher productivity, but also in all factors provided by adequate nutrition, such as better sanity and production quality.

The plant nutrition has influence on its resistance or susceptibility to the attack of diseases, productivity and final quality of the product. Factors such as acidity content and ${ }^{\circ}$ Brix may influence the acceptability of carrots in the market place. Studies in other fruit species showed that potassium splitting contributes to the increase of sugar content (BISSANI et al., 2008; BONETTI et al., 2011)

In tropical soils, potassium reaches concentrations ranging from 0.9 to $19 \mathrm{~g} \mathrm{~kg}^{-1}$, with an average of $20 \mathrm{mg} \mathrm{L}^{-1}$ in the soil solution (ERNANI et al., 2007). The potassium is the macronutrient that is most extracted by carrot plant, and may interpose with the absorption of other nutrients such as nitrogen, calcium, sulfur, phosphorus and magnesium (BISSANI et al., 2008). Potassium fertilization is usually carried out under topdressing method as described by Raij et al. (1997), and should be divided according to the efficient use of the nutrient by plants and avoiding wounding the leaves due to their salt content. Büll et al. (2001) verified that the elevation of potassium levels at the planting-soil provided an increase in the production of bulbs on garlic crop, and this was not influenced by changing potassium levels fertilization on topdressing.

According to Luz et al. (2009), splitting potassium does not necessarily represent an increase in productivity, but rather an improvement in the quality and quantity of carrot marketable roots. Other studies suggested that potassium significantly improves carrot growth expressed by plant height, leaf number, fresh and dry leaf weight and yield, dry root weight, root length and diameter (EL-TOHAMY et al., 2011).

The objective of this study was to evaluate different potassium doses by topdressing fertilization and its influence on the growth, health, productivity and quality parameters of the carrot "Brasília Irecê" variety. 


\section{MATERIAL AND METHODS}

The experiment was carried out at the Federal University of Mato Grosso, 11050'53 "S and $50^{\circ} 38^{\prime} 57^{\prime \prime} \mathrm{W}$, with $384 \mathrm{~m}$ of altitude and climate classified according to Köppen as tropical (Aw). Average temperature was $24{ }^{\circ} \mathrm{C}$ and the average annual rainfall of $2500 \mathrm{~mm}$. The soil of the area is classified as Oxisol, being chemically characterized with $\mathrm{pH}$ in water of 5.17, phosphorus content of $1.96 \mathrm{mg} \mathrm{dm}^{-3}$, potassium content $56 \mathrm{mg} \mathrm{dm}^{-3}$, calcium content $0.96 \mathrm{mg}$ $\mathrm{dm}^{-3}$, magnesium content $0.31 \mathrm{cmol}_{\mathrm{c}} \mathrm{dm}^{-3}$, cation exchange capacity (t) $1.51 \mathrm{cmol}_{\mathrm{c}} \mathrm{dm}^{-3}$, cation exchange capacity (T) $22 \mathrm{cmol}_{\mathrm{c}} \mathrm{dm}^{-3}$ and base saturation (\%) 27.06 .

The soil was prepared with mechanical plowing at $0.8 \mathrm{~m}$ in width and $0.3 \mathrm{~m}$ in depth. The soil acidity was corrected thirty days before planting, with the application of dolomitic limestone (PRNT 80\%) aiming at raising the base saturation to $80 \%$. Planting fertilization was performed according to Ribeiro et al. (1999) with $400 \mathrm{~kg} \mathrm{ha}^{-1}$ of $\mathrm{P}_{2} \mathrm{O}_{5}$ applied at the time of planting, $2 \mathrm{~kg}$ $\mathrm{ha}^{-1}$ of Boron (borax) and Zinc (zinc sulphate). Nitrogen fertilization was carried out with ammonium sulphate $\left[\left(\mathrm{NH}_{4}\right)_{2} \mathrm{SO}_{4}\right]$ at $120 \mathrm{~kg} \mathrm{ha}^{-1}$, with $36 \mathrm{~kg}$ at sowing, $42 \mathrm{~kg}$ at $30^{\text {th }}$ day after sowing and $42 \mathrm{~kg}$ at $50^{\text {th }}$ day after sowing.

The treatments were organized in randomized blocks with three replicates, and the experimental plots with $2 \mathrm{~m}$ length. The treatments were represented by $\mathrm{K}_{2} \mathrm{O}$ doses, calculated from $320 \mathrm{~kg} \mathrm{ha}^{-1} \mathrm{~K}_{2} \mathrm{O}$ (Ribeiro et al., 1999), being: (i) $64 \mathrm{~kg} \mathrm{ha}^{-1}$ (20\% of total dose), (ii) $128 \mathrm{~kg}$ $\mathrm{ha}^{-1} 40 \%$ of total dose), (iii) $192 \mathrm{~kg} \mathrm{ha}^{-1}$ (60\% of total dose), (iv) $256 \mathrm{~kg} \mathrm{ha}^{-1}$ (80\% of total dose), (v) $320 \mathrm{~kg} \mathrm{ha}^{-1} \mathrm{~K}_{2} \mathrm{O}$ (ideal dose), (vi) $384 \mathrm{~kg} \mathrm{ha}^{-1}$ (120\% of total dose), (vii) $448 \mathrm{~kg} \mathrm{ha}^{-1}$ (140\% of total dose), (vi) $512 \mathrm{~kg} \mathrm{ha}^{-1}$ of total dose), (160\% of the recommended dose). The $\mathrm{K}_{2} \mathrm{O}$ doses were applied at three different periods as it follows: $20 \%$ at sowing, $40 \%$ at $30^{\text {th }}$ day after sowing and $40 \%$ at $50^{\text {th }}$ day after sowing.

The carrot seeds were sown on July $30^{\text {th }}, 2010$, using carrot cultivar Brasília Irecê, with a cycle of approximately a hundred and ten days. The cultivar has a slightly conical cylindrical shape and light orange color, with root length varying from 15 to $16 \mathrm{~cm}$ and moderate tolerance to Alternaria (Alternaria dauci). Seeding was done manually with seeds placed between 1.5 to $2.0 \mathrm{~cm}$ deep, rows spaced $0.25 \mathrm{~m}$ and thinning performed thirty days after emergence maintaining a stand of 25 plants $\mathrm{m}^{-1}$. Fungicide management was not used to verify the true effect on $\mathrm{K}$ doses. Pest control was carried out using the insecticides Decis 50SC $\left(7.5\right.$ gia ha $\left.^{-1}\right)$ and fersol ${ }^{\circledR}$ acephate $\left(750\right.$ gia ha $\left.^{-1}\right)$ with $100 \mathrm{~L} \mathrm{ha}^{-1}$ at 15, 30, 60 and 80 days after emergence of the plants and 
control of weeds carried out manually. All plots were irrigated by spraying twice a day, until thirty days after sowing and after this period to maintain the soil with $80 \%$ of field capacity.

The leaf blight (Alternaria dauci) was evaluated at the final stage, at 95 days after emergence by randomly analyzing 10 plants for each treatment. For the evaluation, a scale of injury level grades was used, which ranged from 1 to 5 following modified methodology by Aguilar et al. (1986) where "1" is equivalent to absence of symptoms, "2" perception of small sparse lesions, "3" larger and more frequent lesions surrounded by yellow ring, "4" abundant lesions followed by a strong presence of yellowish ring and " 5 "lesions throughout the leaf, showing signs of senescence.

The results were expressed by percentage (\%), considering the notes average and the notes or levels of the lesions in each plant at 95 days. The grades were assigned respecting the highest level of disease (grade 5), if only one plant was infected considered a $10 \%$ infestation. Generally, treatments with higher levels (notes) of infection presented higher percentage of plants with the disease.

In November 10th, 2010, it was evaluated at the height of the last leaf, in 10 plants plot $^{-1}$. Afterwards, leaf area was checked with an integrator model LI-3100C AREA METER®. The length and diameter of the root were measured with a digital calliper. The productivity was determined by weighing the roots of 10 plants considering stand of 25 plants $\mathrm{m}^{-1}$. Afterwards, roots were ground in an industrial blender forming a composite sample. The soluble solids were checked by Atago digital refractometer and the results expressed by ${ }^{\circ}$ Brix. The acidity was determined by titration with $\mathrm{NaOH}$ and expressed as a percentage of malic acid ( $\mathrm{g}$ of malic acid per $100 \mathrm{~g}$ of fresh tissue), according to techniques standardized by Adolfo Lutz Institute (Brazil, 2005).

The quantitative data were submitted to variance analysis and when significant compared by Tukey test $(\mathrm{p} \leq 0.05)$ and subjected to regression analysis. The qualitative parameters were transformed by using the equation $\sqrt{x+1}$ for normalization purposes.

\section{RESULTS AND DISCUSSION}

Effect of potassium doses on productivity, root length and height of carrot leaf were verified (Table 1). This result was not observed for leaf area, soluble solids content, root diameter 
and titratable acidity. The non-significant results can be justified by the fact that $\mathrm{K}$ is an element that has little influence on the morphological development of plants (MEURER, 2006). However, it is important to note that the benefits of $\mathrm{K}$ in the quality of harvested products cannot be ignored in the economic analysis of potassium fertilization (FURTINI NETO et al., 2001). Potassium is the enzymatic activator of the starch synthesis and the main nutrient related to the yield quality, to the activation of several enzymes during the biosynthesis of photoassimilates, and to the transport of carbohydrates from the source (leaf) to the drains (roots) (TAIZ \& ZEIGER, 2004).

There was a positive and significant correlation between root length and $\mathrm{K}_{2} \mathrm{O}$ (Figure 1). The length ranged from 12 to $14 \mathrm{~cm}$, being classified as extra A, which varies from 12 to $17 \mathrm{~cm}$ (Figure 1) according to Schuphan (1976). This result is indicative that adequate plant nutrition may represent higher productivity and that potassium is inserted in this context.

Table 1. Morphological parameters and quality of Brasília Irecê carrots under potassium topdressing doses. (Sinop, State of Mato Grosso, Brazil, 2010).

\begin{tabular}{|c|c|c|c|c|c|}
\hline $\begin{array}{c}\text { Dose } \mathrm{K}_{2} \mathrm{O} \\
\mathrm{Kg} \mathrm{ha}^{-1}\end{array}$ & $\begin{array}{l}\text { Root diameter } \\
(\mathrm{cm})\end{array}$ & $\begin{array}{l}\text { Leaf area }\left(\mathrm{cm}^{2}\right. \\
\left.\text { plant }^{-1}\right)\end{array}$ & $\begin{array}{l}\text { Lenght leaf } \\
(\mathrm{cm})^{*}\end{array}$ & $\begin{array}{l}\text { Total } \\
\text { Accidity }\end{array}$ & $\begin{array}{l}\text { Sugar Content } \\
\text { ('Brix) }\end{array}$ \\
\hline 64 & $2.62^{\mathrm{ns}}$ & $760.53^{\mathrm{ns}}$ & $48.20 \mathrm{~b}$ & $2.95^{\mathrm{ns}}$ & $7.66^{\mathrm{ns}}$ \\
\hline 128 & 2.82 & 968.80 & $51.93 \mathrm{a}$ & 3.25 & 8.00 \\
\hline 192 & 2.21 & 707.73 & $50.32 \mathrm{ab}$ & 3.02 & 7.33 \\
\hline 256 & 2.79 & 797.13 & $47.53 \mathrm{~b}$ & 2.88 & 7.66 \\
\hline 320 & 3.17 & 1089.33 & $52.66 \mathrm{a}$ & 3.17 & 7.66 \\
\hline 384 & 3.13 & 877.46 & $52.65 \mathrm{a}$ & 3.28 & 8.00 \\
\hline 448 & 3.07 & 812.60 & $51.37 \mathrm{ab}$ & 3.32 & 9.00 \\
\hline 512 & 3.42 & 976.33 & $50.91 \mathrm{ab}$ & 3.12 & 7.66 \\
\hline $\mathrm{CV}(\%)$ & 17.96 & 41.97 & 7.94 & 20.76 & 13.40 \\
\hline
\end{tabular}

": Significant by Tukey test with (p $\leq 0.05)$. ${ }^{\text {ns: }}$ Not significant by Tukey test with $(\mathrm{p} \leq 0.05)$.

There was no significant difference in soluble solids content and acidity between the different $\mathrm{K}$ doses (Table 1). The $\mathrm{K}$ is considered the "quality nutrient"; however, it can be observed that, in this study, for the carrot crop, the results were not expressive. These results corroborate with Shibairo et al. (1998), where the authors verified that the K did not provide increase of acidity and the soluble solids content in the carrot culture.

The beneficial action of K may vary from species to species. Fontes et al. (2000) verified in the tomato crop that the potassium increased the content of total acidity and sugars of the fruits. In watermelon, $\mathrm{K}$ fertilization increased the soluble solids content, thickness and bark resistance (DESWAL \& PATIL, 1984). In Oxisol, Bonetti et al. (2011) was studied the 
importance of potassium distribution in the melon crop, and was found a positive influence on the solids content and acidity, differing from the results observed for the carrot crop. Other results suggest that $\mathrm{K}$ can improve carrot productivity and quality, with higher productivity and better morphological development (EL-TOHAMY et al., 2011). The nutritional factors of the plant and the source of nitrogen (ammonium sulphate) may engage with potassiun (ERNANI et al., 2007), limiting the absorption or even the translocation of this nutrient by the plant. There was an increase in the yield as a function of increasing $\mathrm{K}_{2} \mathrm{O}$ doses. The highest productivity was obtained at the dose of $448 \mathrm{~kg} \mathrm{~K}_{2} \mathrm{O} \mathrm{ha}{ }^{-1}$ (Figure 2).

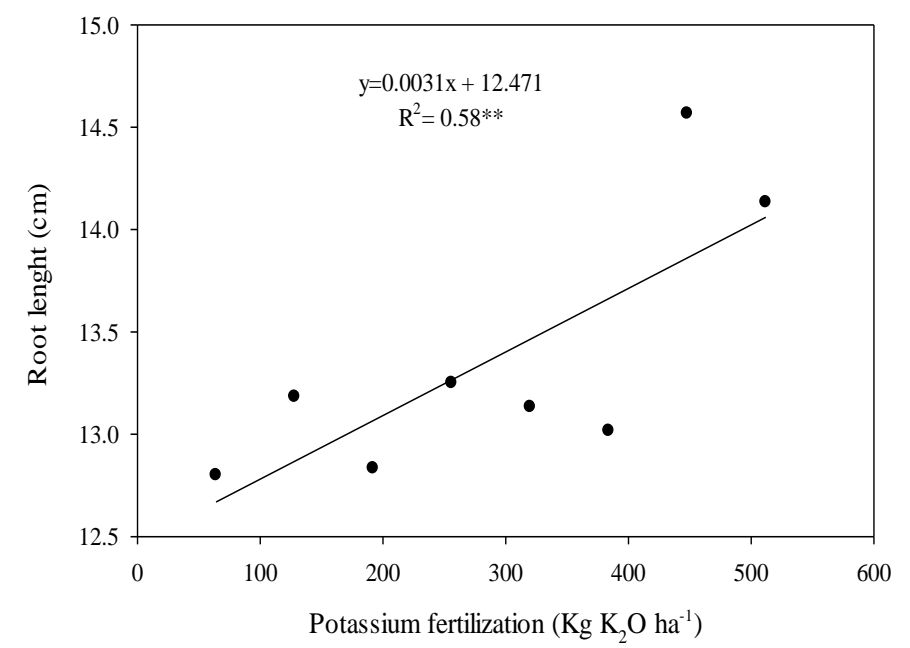

Figure 1. Carrot root length of Brasilia Irecê under $\mathrm{K}_{2} \mathrm{O}$ doses. Sinop, State of Mato Grosso, Brazil (November, 2010).

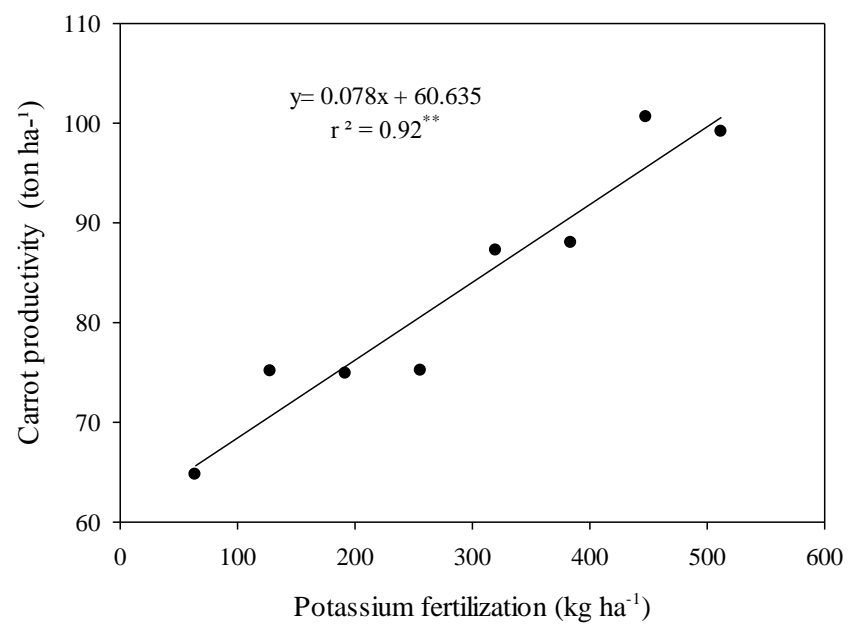


Figure 2. Productivity of carrots Brasilia Irecê in function of $\mathrm{K}_{2} \mathrm{O}$ applicated. Sinop, State of Mato Grosso, Brazil (November, 2010).

The highest productivity is due to the fact that potassium is indispensable in the translocation and storage of photoassimilates being essential for growing, development of the grains and fruits of the plants (MEURER, 2006). The increase of productivity occurs due to the better development of the roots and better health of the crop, being directly related with the incidence of diseases. Taiz \& Zeiger (2004) comment that the splitting of different doses of $\mathrm{K}_{2} \mathrm{O}$ can mean increase of productivity. In this study, the higher dose of potassium did not provide maximum yield. According to Furtini Neto et al. (2001) occur high responses to initial nutrient doses, but reduction in production with an increase in the amount of fertilizer supplied.

There was high correlation between yield and root length $\left(r^{2}=0.71\right)$, influenced by $\mathrm{K}_{2} \mathrm{O}$ doses (Figure 3).

The root development was important to increased yield, and this may be beneficial for in natura marketing products. Also in this study, was verified that high potassium levels reduced incidence of leaf blight (Alternaria dauci) (Figure 4).

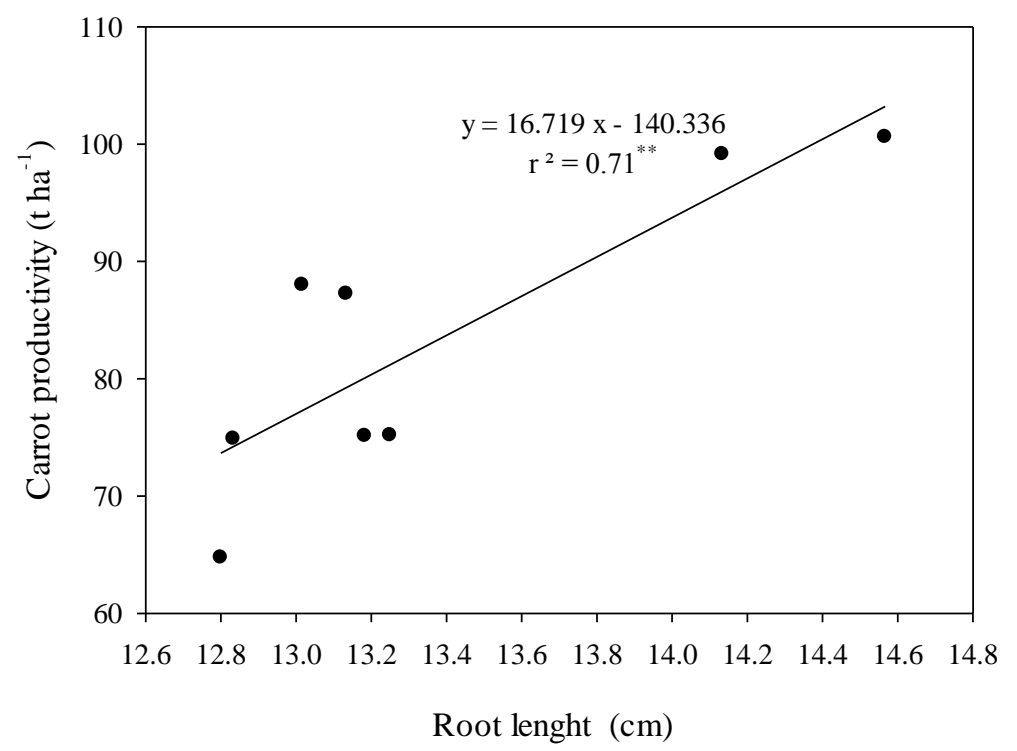

Figure 3. Relationship between root length and yield of Brasília Irecê carrots as a function of $\mathrm{K}_{2} \mathrm{O}$ doses in topdressing. Sinop, State of Mato Grosso, Brazil (November, 2010). 


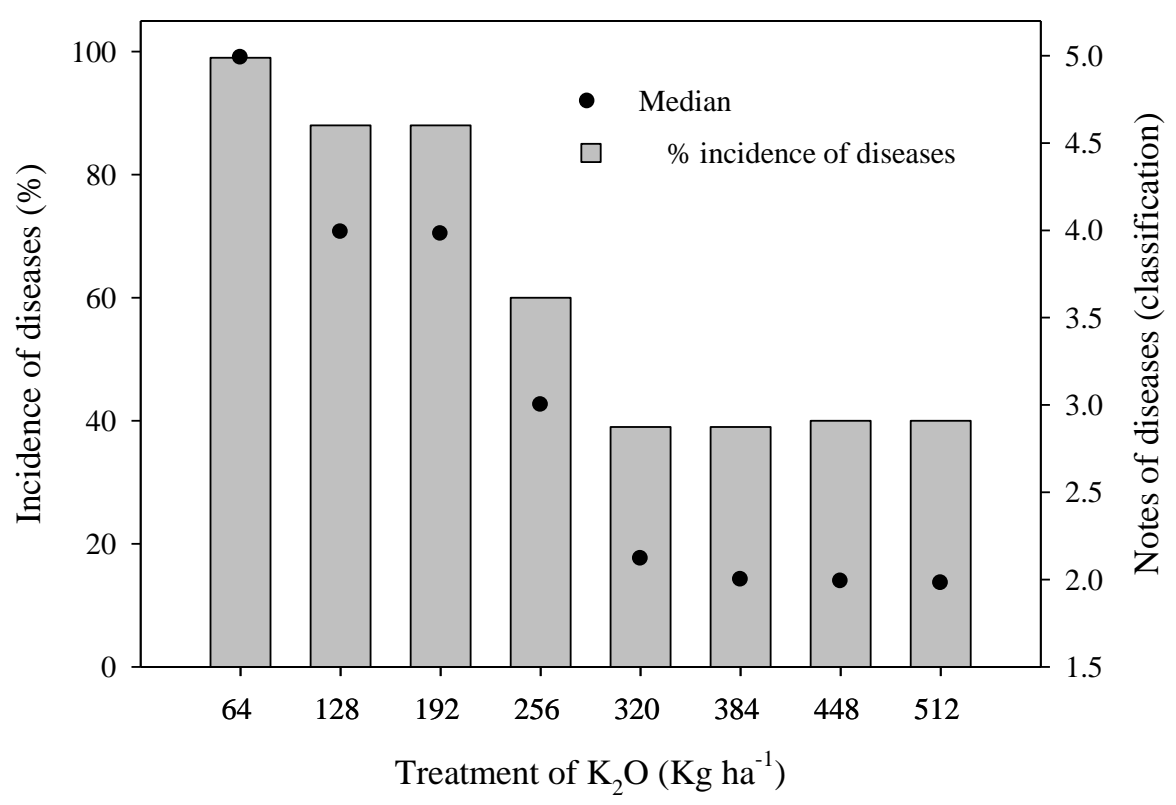

Figure 4. Percentage of infected plants by leaf blight (Alternaria dauci) at 95 days, in relation to the respective grades of disease levels, expressed as percentage in Brasília Irecê carrot, with $\mathrm{K}_{2} \mathrm{O}$ dose applied in topdressing. Sinop, State of Mato Grosso, Brazil (November, 2010).

Potassium dose lower than $320 \mathrm{~kg} \mathrm{~K}_{2} \mathrm{O}$ ha $^{-1}$ showed more incidence of leaf blight and above it, there was stabilization of the incidence of the disease. Within each grade can be observed the percentage of infected plants (Figure 4). At the dose of $64 \mathrm{~kg}$ of $\mathrm{K}_{2} \mathrm{O} \mathrm{ha}{ }^{-1} 99 \%$ of the plants were infected with level 5 lesion. These values were reduced, and $40 \%$ of the plants were infected with a level 2 lesion.

For Vintal et al. (1999), reducing the rate of fertilization by half over the recommended doses results in a 23-30\% increase in leaf blight severity and doubling the fertilization rate results in only a 10-15\% decrease in disease severity. Other studies, such as Furtini Neto et al. (2001) cite that $\mathrm{K}$ acts in reducing the incidence of diseases in carrot culture. At the ideal dose $(320 \mathrm{~kg}$ $\mathrm{ha}^{-1} \mathrm{~K}_{2} \mathrm{O}$ ) there was a reduction in disease incidence, showing the same tendency towards the higher doses. This refers to a special attention with the potassium fertilization and its installment, which results in gain of productivity and reduction of expenses with applications of phytosanitary products in the carrot crop. 


\section{CONCLUSIONS}

The linear potassium doses increase root length, leaf height and yield of Brasília Irecê carrot.

There is a positive correlation between yield and root length of carrot.

The increase of potassium doses above $320 \mathrm{~kg}$ of $\mathrm{K}_{2} \mathrm{O}$ can reduce the incidence of leaf blight.

\section{REFERENCES}

AGUILAR, J. A. E.; REIFSCHNEIDER, F. J. B.; ROSSI, P. F. E.; DELLA VECCHIA, P. T. 1986. Nível de resistência de cenoura a Alternaria dauci e interação com tratamento químico. Horticultura Brasileira, Brasília, v. 4, n. 2, p. 19-22.

BISSANI, C. A.; GIANELLO, C.; CAMARGO, F. A. O.; TEDESCO, M. J. 2008. Fertilidade do solo e manejo da adubação de culturas. $2^{a}$ ed. Porto Alegre, Metrópole. 344p.

BONETTI, J. A.; ZANUZO, M. R.; CONSTANTINO, E. J.; CACHO, R. C.; RIEGER, F. A. 2011. Influência do parcelamento de potássio (K) nas características do melão em sistema tutorado Sinop-MT. Revista Uniara, Araraquara, v.14, n. 1, p.107-114.

BRASIL. 2005. Ministério da Saúde. Agência Nacional de vigilância Sanitária. Métodos físicoquímicos para análise de alimentos. Brasília, Ministério da Saúde. 1018p.

BÜLL, L. T.; BÔAS, R. L. V.; FERNANDES, D. M; BERTANI, R. M. A. 2001. Fertilização potássica na cultura do alho vernalizado. Scientia Agrícola, Piracicaba, v.58, n. 1, 157-163.

DESWAL, I. S.; PATIL, V. K. 1984. Effects of N, P and K on the fruit of water melon. Journal of Maharashtra Agricultural Universities, [S.1.] v. 9, n. 3, p. 308-309.

EL-TOHAMY, W. A.; EL-ABAGY, H. M.; BADR, M. A.; ABOU-HUSSEIN, S.D.; HELMY Y. I. 2011. The Influence of Foliar Application of Potassium on Yield and Quality of Carrot (Daucus carota L.) Plants Grown under Sandy Soil Conditions. Australian Journal of Basic and Applied Sciences, Pakistan, v. 5, n. 3, p. 171-1741.

ERNANI, P. R.; ALMEIDA, J. A. \& SANTOS, F. C. 2007. Potássio. In: Novais, R.F.; Alvares, V. V. H.; Barros, N. F.; Fontes, R. L. F.; Cantarutti, R. B.; Neves, J. C. L. (Eds.) Fertilidade do solo. Viçosa, Sociedade Brasileira de Ciência do Solo. p. 551-594.

FONTES, P. C. R.; SAMPAIO, R. A.; FINGER, F. L. 2000. Fruit size, mineral composition and quality of trickle-irrigated tomatoes as affected by potassium rates. Pesquisa Agropecuária Brasileira, Brasília, v. 35, n. 1, p. 21-25.

FURTINI NETO, A. E. F.; VALE, F. R.; RESENDE, A.V.; GUILHERME, L. R. G.; GUEDES, G. A. A. 2001. Fertilidade do Solo. Lavras, UFLA/FAEPE. 252p.

LUZ, J. M. Q.; JÚNIOR, J. A. S.; TEIXEIRA, M. S. S. C.; SILVA, M. A. D.; SEVERINO, G. M.; MELO, B. 2009. Desempenho de cultivares de cenoura no verão e outono-inverno em Uberlândia-MG. Horticultura Brasileira, Brasília, v.27, n.1, p. 96-99.

MEURER, E. J. 2006. Potássio. In: Fernandes, M. S. (Ed.). Nutrição Mineral de Plantas. Sociedade Brasileira de Ciência do Solo. Viçosa, p. 293-312.

RAIJ, J. B.; QUAGGIO, J. A. \& FURLANI, A. M. C. 1997. Recomendações de adubação e calagem para o estado de São Paulo. $2^{\mathrm{a}}$ ed. Campinas, IAC. 285p. 
SHIBAIRO, S.; UPADAHYAYA, M. K. \& TOIVONEN, P, M. A. 1998. Potassium nutrition and postharvest moisture loss in carrots (Daucus carota L.) Journal of Horticultural Science \& Biotechnology, Abingdon, v. 73, n.3, p. 862-866.

SHIBATA, E. T.; REIS, A.; VIEIRA, J.V. 2008. Reação de cultivares de cenoura à queima das folhas em campo e a Alternaria dauci em casa-de-vegetação. Boletim de Pesquisa e Desenvolvimento, Brasília: Embrapa Hortaliças, 14p.

SCHUPHAN, W. 1976. Mensch und nahungspflanze: Der biologische wert der nahungspflanze in abhaengigkeit von pestizideinsatz, boden qualitat und dungung.Der Haag, Edenstiftung. 190p.

TAIZ L \& ZEIGER E. 2004. Fisiologia Vegetal. $3^{\mathrm{a}}$ ed. Porto Alegre, Artmed. 719p.

VINTAL, H.; BEM-NOON, E.; SHLEVIN, E.; YERMIYAHU, U.; SHTIENBERG, D.; DINOOR, A. 1999. Dino of Influence of Rate of Soil Fertilization on Alternaria Leaf Blight (Alternaria dauci) in Carrots. Phytoparasitica, Michigan, v. 27, n. 3, p. 193-200. 